Ann. Biol. anim. Bioch. Biophys., I973, 13 (3), 32 I-328.

\title{
PASSAGE AND DISAPPEARANCE OF LABELLED SPERMATOZOA IN THE GENITAL TRACT OF THE MALE JAPANESE QUAIL IN SEGREGATION OR COHABITATION ${ }^{(1)}$
}

\author{
D. AMIR, Batia BRAUN-EILON and H. SCHINDLER \\ Division of Animal Reproduction, Agricultural Research Organization, \\ The Volcani Center, P.O.B. 6, Bet Dagan, Israel
}

\section{SUMMARY}

Male quails kept in segregation from or in cohabitation with females were injected with ${ }^{3} \mathrm{H}$-thymidine and the passage of labelled spermatozoa through the epididymis and the vas deferens was followed by autoradiography.

Labelled spermatozoa appeared in the epididymis on the $\mathrm{I} I$ th day after injection and reached the distal part of the vas deferens within 24 hours both in segregated males and in those kept with females.

Three sperm populations with decreasing intensity of labelling were identified in the epididymis on days I I, I 4 and I 5 , and in the distal part of the vas deferens on days I 2 , I 5 and 16 after injection.

From the distribution of labelled spermatozoa along the vas deferens of the males of the two groups, it was concluded that some slowing down in the transit of the main bulk of the spermatozoa had occurred in the males kept isolated from females. This fact indicated the role of the vas deferens as a transitory storage place of the segregated males, unejaculated spermatozoa which were eliminated about $24 \mathrm{~h}$ later than those of the males kept in cohabitation with females.

\section{INTRODUCTION}

MunRo (I938) showed that cock spermatozoa acquire motility and fertilizing capacity during their passage through the epididymis and the proximal part of the vas deferens. Using indirect methods, he concluded that the duration of sperm transit through the excretory ducts is 24 hours in sexually active males but the transit " may require 72 to 96 hours " in non-active males. Using autoradiography, de RE-

(1) Contribution from the Agricultural Research Organization, The Volcani Center, P. O.8. 6, Bet Dagan, Israel. 1972 Series, No. 222 I-E. 
VIERS (I968) found that in regularly " collected " cocks the spermatozoa passed through the vas deferens within $I$ to 3 days, according to season.

MuNRo (I938) attributed no storing function to the vas deferens, but LAKE (I957) and GLOVER and NICANDER (I97I), on the grounds of anatomical and histological considerations, came to the conclusion that in the domestic cock the vas deferens does serve as a transitory storage place for spermatozoa. Also de REVIERS (1972), by counting the sperm reserves in the vas deferens of " collected " and " noncollected " cocks, concluded that the distal part of the vas deferens serves as a storage organ for unejaculated spermatozoa.

In view of the functions of the excurrent ducts of the domestic fowl as organs for the maturation and storage of spermatozoa, the present study was undertaken in order to study both the duration of sperm transit under different sexual regimes and the role of the vas deferens as a sperm storage organ in the Japanese quail. This was done by following the transit and the rate of disappearance of spermatozoa which had been labelled with ${ }^{3} \mathrm{H}$-thymidine. This method, used previously by de REVIers (I968) in cocks, enables us to distinguish between and to follow different sperm populations under normal physiological conditions. These advantages cannot be achieved by the use of India ink, or by the production of spermatozoal abnormalities with X-rays, methods employed by MunRo (r938).

\section{MATERIALS AND METHODS}

Male Japanese quails which had been kept from puberty until the start of the experiment in isolation from females, were used. During rearing as well as during the experiment they were maintained under continuous light by supplying artificial illumination during the hours of darkness. The birds were injected intraperitoneally with $100 \mu \mathrm{Ci}$ of ${ }^{3} \mathrm{H}$-thymidine $(\mathrm{x}-26 \mathrm{Cim} / \mathrm{M}$-, C.E.A., France) in $0.5 \mathrm{ml} 9 \mathrm{p} .100 \mathrm{NaCl}$ sterile solution.

In the first series of experiments 30 males, three per cage, were used. Beginning $I h$ after injection, two males were killed each day until the $4_{4}$ th day, by intracardial injection of $0.5 \mathrm{ml}$ Nembutal (Abbott Laboratories, Ltd.). One testis, with the adjacent epididymis and vas deferens, was removed immediately. The vas deferens was divided by ligatures into the proximal, middle and distal parts. These segments, after having been stretched on cardboard, as well as the epididymis and a portion of the testis, were fixed in a 95 -ethanol-formol-acetic acid (75-20-5) fixative for $24 \mathrm{~h}$, embedded in paraffin, and cut in $4 \mu$ sections. The parts of the vas deferens were cut longitudinally.

In the second series of experiments two groups of 30 males each were used : (a) three males per cage, and $(b)$ one male with two females per cage. Two males from each group were killed each day from the Ioth to $24^{\text {th }}$ day after injection. Homogenates of the epididymis and the three segments of the vas deferens were prepared using a slow gear homogenator and $0.25 \mathrm{ml}$ of an isotonic phosphate buffer $(\mathrm{pH} 7.2)$ containing 3 p. Ioo PVP( $\left.{ }^{1}\right)$, to avoid swelling and disintegration of the cells (SCHINDLER and KEMPENICH-PINTO, personal communication). Smears were prepared from the homogenates as well as from homogenates from non injected birds. The sections and the smears were mounted on Ilford coated slides and dipped in $K_{2}$ and $K_{5}$ Ilford radioautographic emulsion, respectively. After 3 weeks of exposure of the sections and one month of exposure of the smears, the slides were developed in an Amidol developer (FERRAGI, r952) and stained with Mayer's haemalum solution, except for the sections from the testes, which were stained with haematoxylin eosin.

On each smear the percentage of labelled spermatozoa was determined by a random count of at least 500 spermatozoa, using oil immersion ( $\times$ I 500$)$. The intensity of labelling was determined by counting the number of silver grains above the head of each labelled spermatozoon. Observations of smears prepared from non-injected birds or from unlabelled parts of injected males revealed that fewer than $I$ p. Ioo of the spermatozoa were associated with background clusters of two or more grains in one lot of autoradiograms and three or more grains in a second

(1) Polyvinylpyrrolidone (Sigma, U.S. A.). 
lot. Thus, spermatozoa with three and four or more silver grains/nucleus for the two lots of autoradiograms, were considered as labelled. The labelled spermatozoa were divided into ten classes according to the number of grains above their heads, the last class being the one which included the spermatozoa having more than 29 or 30 grains. It was impossible to count with accuracy more than 30 grains over the strongly labelled spermatozoa.

\section{Analysis of results}

According to the labelling intensity of the spermatozoa, different sperm populations and t) eir arrival in the epididymis and the distal part of the vas deferens at different intervals after the injection of the precursor, were presented graphically according to the method of LAzAR and C.ERARD-Marchant (rg65). This method allows the linear representation of the cumulated frequencies of labelled spermatozoa, by plotting these frequencies, on a probit scale, against the logarithm of the maximum number of silver grains of each of the ten classes of labelled sperma. tozoa. All the spermatozoa which were found labelled among the 500 or more sperm cells counted in each bird, served for the calculation of each labelled sperm population (average of 240 labelled spermatozoa for each population).

\section{RESULTS}

The incorporation of the injected precursor into the germ cells, their advancement up to spermatozoa in the testis, and the passage of the labelled spermatozoa through the epididymis and the vas deferens of segregated males, were followed in autoradiograms of histological sections of these organs (transverse sections for the testis and the epididymis and longitudinal sections for the vas deferens).

Labelled primary spermatocytes found one hour after injection evolved to round spermatids on the $7^{\text {th }}$ day and to elongated spermatids and spermatozoa on the 9 th and roth days. On the IIth day a great number of strongly labelled spermatozoa entered the epididymis and the proximal part of the vas deferens (Plate I, fig. $I, 2,3)$, and some of them reached the upper portion of the middle part of the ductus. On the I2th day the middle and distal parts of the vas deferens contained many labelled spermatozoa (Plate I, fig. 4), whereas in the epididymis and the proximal part of the ductus, such spermatozoa were present only in small numbers.

On the $3^{\text {th }}$ day only a few radioactive spermatozoa were found in the excurrent ducts, but on the I4th day many such spermatozoa entered the epididymis and the proximal part of the vas deferens again.

Having established the times of appearance of labelled spermatozoa in the different parts of the excurrent ducts in segregated males, the influence of copulation on the rate of passage of these spermatozoa through the epididymis and the vas deferens was studied in autoradiograms of smears prepared from the different parts of the genital tract in males kept in segregation or cohabitation. The percentages of labelled spermatozoa and the intensity of their labelling were scored. The examinations were carried out until no more labelled spermatozoa were found. The results are presented in table $\mathbf{I}$.

From the fact that labelled spermatozoa in both segregated and cohabiting males entered the epididymis on day II and reached the distal part of the vas deferens on day I2 (table I), as was established also in the first experiment, it appears that the sperm transit through the excurrent ducts of the male quail can be accom- 
plished within $24 \mathrm{~h}$. But table I also shows that the distribution of labelled spermatozoa along the vas deferens was different in the two groups of males. On day Ir fewer labelled spermatozoa reached the proximal part of the vas deferens of segregated males (I4 p. IOo) than of those kept with females (4I p. IOO). In accordance, more labelled spermatozoa remained in the middle and distal parts of the ductus on days $\mathrm{I} 2$ and $\mathrm{I} 7$ in segregated birds than in cohabiting males : on day $\mathrm{I} 2: 53 \mathrm{p}$. Ioo and 26 p. IOo vs. 7 p. Ioo and 20 p. Ioo, and on day $17:$ Io p. IOo and 8-33 p. IOO vs. 2 p. IOO and $3 \mathrm{p}$. Ioo. These facts show that in the segregated males the passage of the main bulk of spermatozoa was slowed down.

\section{TABLE I}

Percentage of labelled spermatozoa in the different parts of the genital tract of the male quail at different days after injection of ${ }^{3} \mathrm{H}$-thymidine

(average of 2 males)

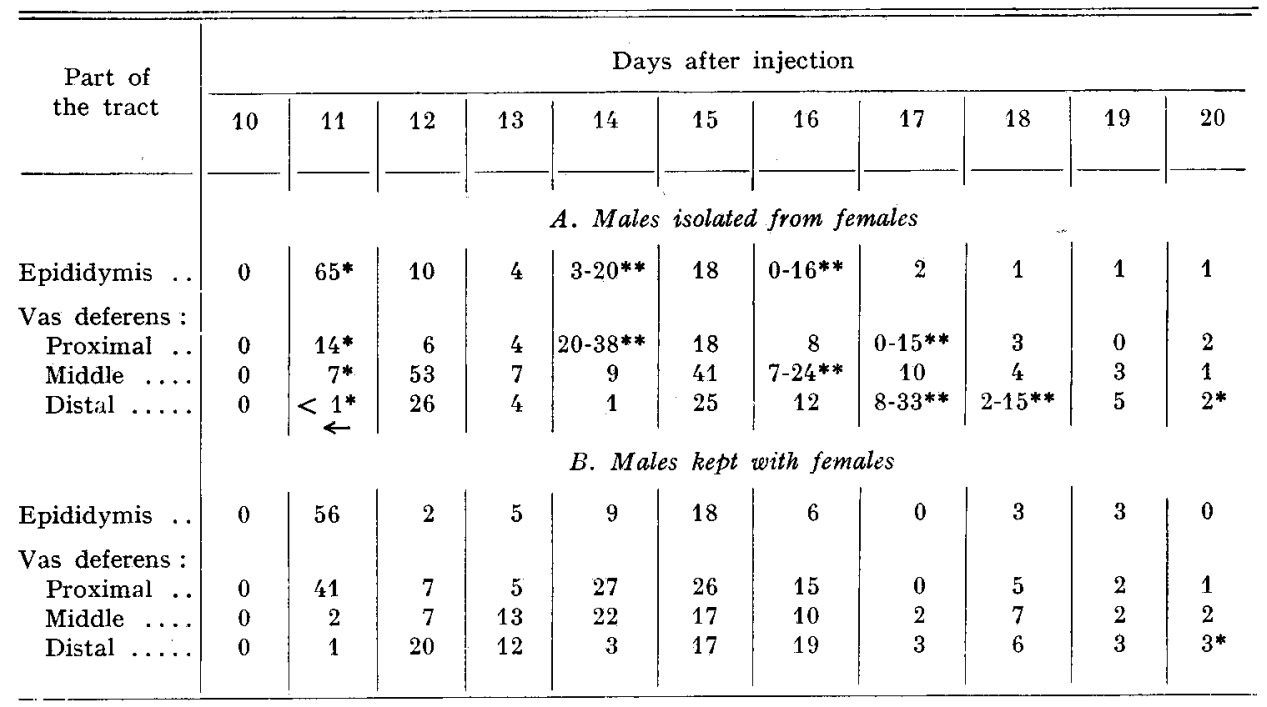

* Data from one animal only.

** Data from both animals.

From Table I it can also be seen that waves of spermatozoa entered the $\epsilon$ pididymis on days II, I4 and I5, whereas in the middle and distal parts of the vas deferens many labelled spermatozoa were found on days I2, I5 and I6. By plotting, for each of these days, the cumulated frequencies of labelled spermatozoa against the $\log$ of the number of grains of these spermatozoa, it was possible to distinguish three sperm populations at the two ends of the excretory duct in both the segregated and the cohabiting males (Text - fig. $I, 2$ ). The mean radioactivity of these populations differed significantly from each other in all except one case.

In the cohabiting males the percentage of labelled spermatozoa in the vas 


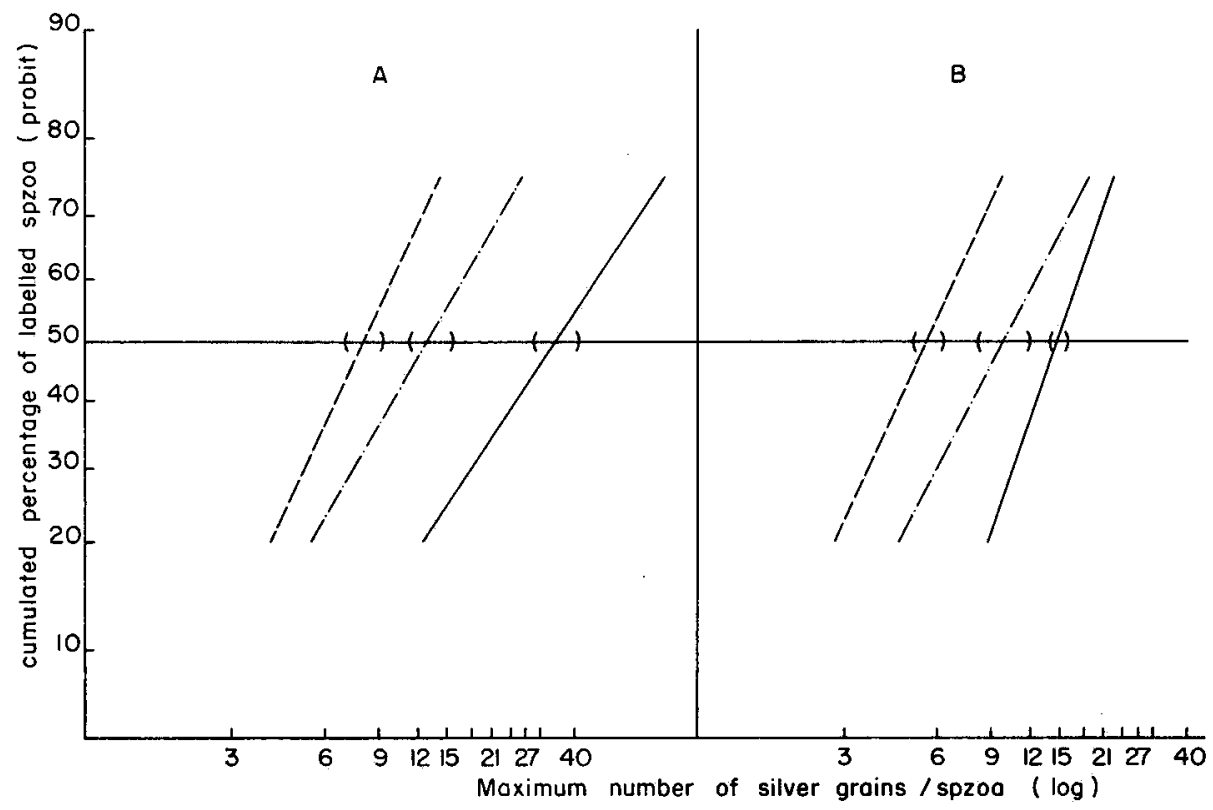

FIC $I$ - Labelling intensity of sperm populations which entered the epididymis of male quails kept in segregation (A) or cohabitation (B) at different days after ${ }^{3} H$-thymidine injection

Day no.
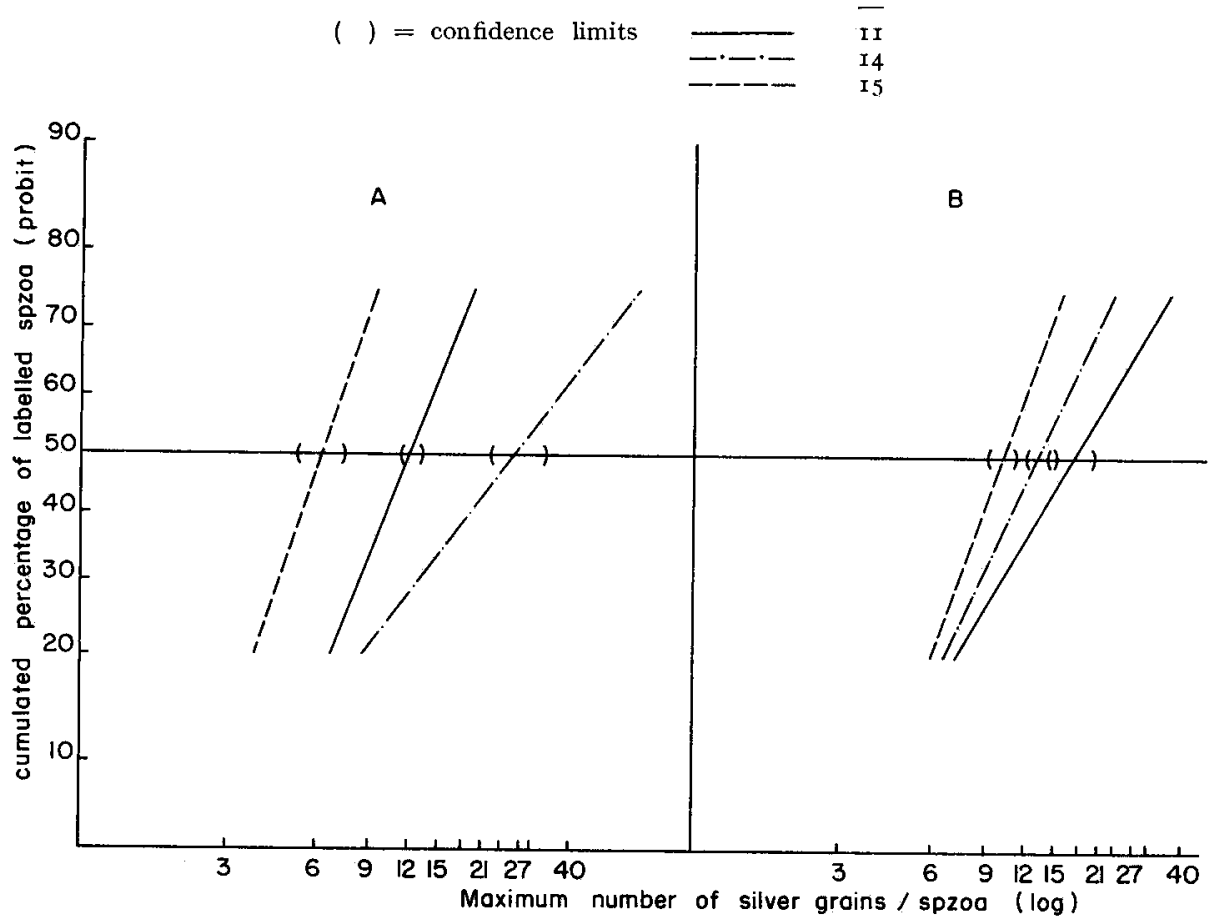

FIG: 2: - Labelling intensity of sperm populations which arrived in the distal part of the ductus deferens of male quails kept in segregation (A) or cohabitation (B) at different days after ${ }^{3} \mathrm{H}$-thymidine injection

Day no.

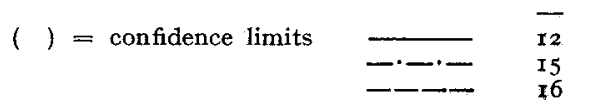


deferens decreased rapidly after the I6th day, whereas in the segregated males this decrease occurred one day later (table I). After the 2oth day fewer than I p. Ioo of the weakly labelled spermatozoa (up to 6 grains/spermatozoon) were found in the different parts of the excurrent ducts in the males of the two groups.

\section{DISCUSSION}

The results of this work show that sperm transit in the male quail can be accomplished within $24 \mathrm{~h}$. Therefore, the three sperm populations of declining labelling intensity which entered the epididymis on days II, I4 and I5, and which were also found in the distal part of the vas deferens on days $I 2, I 5$ and $I 6$, can be considered as corresponding ones passing through the ductus in about one day. The decline of the average intensity of labelling can be attributed to the additional divisions of the germ cells from which these sperm populations issued. The rate of this decline was indeed close to the theoretical relationship of $4: 2: 1$. The actual deviations from this relationship may arise from (a) possible differences in the duration of DNA synthesis between the different types of germ cells - as reported for the bull (HocHEREAU, I967), (b) the impossibility to count with accuracy more than 30 grains over the heads of the very strongly labelled spermatozoa and $(c)$ the fact that each sperm population issued from a different pair of animals. In spite of an identical dose of injected precursor, different animals could have been labelled differently, as was observed in rams (AMIR and ORTAVANT, I968).

An unusually stronger labelling of the I5th-day animals may have been one of the causes of the $I 5$ th-day sperm population being labelled more strongly than the r2th-day population in the distal part of the vas deferens of the segregated males. Another possible contribution to this deviation may have been a delay in the release of the strongly labelled spermatozoa from the testes of the I5th-day animals, as reported for rabbits (AMANN, I972) ; however, in none of the six animals killed II days after the injection of the precursor was such a delay in the release of labelled spermatozoa found.

Although no quantitative measurements of the sexual activity of the cohabiting males were made, nor was the possibility of semen emission by the segregated males checked, some slowing down of the sperm transit had occurred in the males kept isolated from females. This is shown by the fact that in these males fewer labelled spermatozoa arrived at the proximal part of the vas deferens on day II and more labelled spermatozoa remained in the middle and distal parts of the vas deferens on days $I 2$ and $\mathrm{x} 7$, than in the males kept with females. In bulls (ORGEBIN-CRIST, I962) and rams (AMIR and ORTAVAN', I968) frequent sperm collections were found to hasten the epididymal transit by ro-30 p. I0o. The slowing down of the rate of sperm transit in the segregated males suggests that the vas deferens can serve as a transitory storage place for unejactilated spermatozoa, as was pointed out by LAKE (I957), Glover and Nicander (I97I) and de ReVIERS (I972) for the cock. The similarity of the distribution of labelled spermatozoa in the vas deferens of the segregated males on day $I 7$ with that of the cohabiting males on day $I 6$, indicates that the storage 
period may be of about one day, as far as could be assessed from the $24 \mathrm{~h}$ intervals at which the observations were made.

After this additional day of remaining in the vas deferens of the segregated males, the spermatozoa were eliminated as in the males kept with females, but one day later.

Reçu pour publication en mars 1973.

\section{ACKNOWLEDGEMENTS}

We appreciate the helpful discussions we have had with Professor P. F. Kraicer. We wish to thank Dr. Hannah BRodA for her advice during the histological work. Professor R. ORTAVANT, Dr. M. Courot and Mr. M. de Reviers are thanked for reading the manuscript and for their useful comments and.suggestions.

\section{RÉSUMÉ}

\section{PASSAGE ET DISPARITION DES SPERMATOZOÏDES MARQUÉS DANS LE TRACTUS GÉNITAL, DE IA CAILLE MÂLE SÉPARÉE OU NON DES FEMELILS}

Des cailles mâles séparées ou non des femelles ont été injectées avec de la thymidine- ${ }^{3} \mathrm{H}$; le passage des spermatozoïdes marqués dans l'épididyme et le canal déférent fut suivi par autoradiographie.

Des spermatozoïdes marqués apparaissent dans l'épididyme le I I ${ }^{\mathbf{e}}$ jour après $1^{\prime}$ injection et sont trouvés dans la partie distale du canal déférent le $12^{\mathbf{e}}$ jour chez les mâles de deux groupes. Le transit des spermatozoïdes dans les voies déférentes de la caille peut donc être accompli dans un délai de $24 \mathrm{~h}$.

Trois populations de spermatozoïdes, d'intensité de marquage décroissante, ont été identifiées dans l'épididyme les jours I I, I4 et I 5 , et dans la partie distale du canal déférent les jours I2, I5, 16. Il semble que ce sont les mêmes populations de spermatozoïdes qui proviennent des différentes générations successives des cellules germinales.

La différence entre les cailles de deux groupes dans la distribution des spermatozoïdes marqués dans les canaux déférents montre que chez les mâles séparés des femelles il y a un ralentissement du transit de la masse principale des spermatozoïdes. Ce fait indique que le canal déférent peut servir comme un lieu de stockage transitoire des spermatozoïdes non éjaculés. Pour autant que des observations espacées de $24 \mathrm{~h}$ permettent d'en juger, ces spermatozoïdes sont éliminés une journée plus tard que chez les mâles maintenus en présence des femelles.

\section{REFERENCES}

AMANN R. P., I972. The effect of variations in the duration of rabbit spermatogenesis on determination of sperm epididymal transit time. VIIth Int. Congr. Anim. Reprod. Attif. Insem., München, Summaries p. $4 \mathrm{I}$.

Amir D., Ortavant R., I 968 . Influence de la fréquence des collectes sur la durée du transit des spermatozoïdes dans le canal épididymaire du Bélier. Ann. Biol. anim. Bioch. Biophys., 8, 195-207.

FARRAGi H., 1952. Détection des éléments radioactifs par la technique photographique : Autoradiographie. Comm. En. atom. France, 27-33.

Glover T. D., Nicander L., I97I, Some aspects of structure and function in the mammalian epididymis. J. Reprod. Fert., Suppl., 18, 39-50. 
Hochereau M.-T., I967. Synthèse de l'ADN au cours des multiplications et du renouvellement des spermatogonies chez le Taureau. Arch. Anat. Micr. Morph. Exp., 56, Suppl. 2-4, 86-96.

LAKE P. E., 1957. The male reproductive tract of the fowl. J. Anat., 91, 116-129.

Lazar P., Gérard-Marchant R., 1965. Une technique de représentation graphique des numérations de grains sur autohistoradiographie. Ann. Histochem., 10, 43-52.

MunRo S. S., I938. Functional changes in the fowl sperm during their passage through excurrent ducts of the male. J. exp. Zool., 79, 7I-92.

ORGEBIN-CRIST M. C, I962. Recherches expérimentales sur la durée de passage des spermatozoïdes dans l'épididyme du Taureau. Ann. Biol. anim. Bioch. Biophys., 2, 5 I-Io8

Reviers M. de, 1968 . Détermination de la durée des processus spermatogénétiques chez le Coq à l'aide de thymidine tritiée. VIe Congr. int. Reprod. anim. Insém. artif., Paris, 1, I83-185.

Reviers M. de, I972. Évaluation des réserves spermatiques dans les voies déférentes du Coq: $A n n$. Biol. anim. Bioch. Biophys., 12, 5-11.

\section{PLATE I}

Histological sections and sperm smear from the epididymis and the vas deferens of segregated males after ${ }^{8} \mathrm{H}$-thymidine injection

(Haemalum stain, $\times$ I 500)

FIG. I, 2

Histological sections of the epididymis Io (fig. I, no labelled spermatozoa) and Ir days (fig. 2, many labelled spermatozoa) after ${ }^{3} \mathrm{H}$-thymidine injection.

\section{FIG. 3}

Sperm smear from the epididymis of a segregated male II days after injection showing strongly labelled spermatozoa.

FIG. 4

Histological section of the distal part of the vas deferens I 2 days after injection (many labelled spermatozoa). 
